\title{
Black walnut, Osage orange and eastern redcedar sawmill waste as natural dyes: effect of aluminum mordant on color parameters
}

\author{
Kelsie Doty ${ }^{1 *}$, Sherry Haar ${ }^{2}$ and Jooyoun Kim $^{2}$
}

\author{
*Correspondence: \\ knd36@cornell.edu \\ ${ }^{1}$ Cornell University, Ithaca, \\ NY, USA \\ Full list of author information \\ is available at the end of the \\ article
}

\begin{abstract}
The triple bottom line can be impacted in both positive and negative ways by the use of tree sawmill waste as a natural dye. Trees contain a biomordant in the form of tannin which may eliminate the need for metallic mordants, thus reducing water, thermal energy, residual waste, and exposure to a mordant chemical. Dyeing with mill waste provides an economic option for an existing timber manufacturing byproduct. This research analyzed the impact of potassium aluminum sulfate (PAS) on dye concentration, hue, and colorfastness to light and laundering for three regional dyewoods (black walnut, Osage orange, and eastern redcedar) on wool yarn. Dye concentrations were pre-tested to find a standard depth of shade between mordanted and nonmordanted yarns. Tests for colorfastness to light and laundering were performed according to AATCC methods. Resulting colors for exposed and unexposed specimens were rated using CIE $L^{*} a^{*} b^{*}$ values and descriptive statistics were used to examine directional relationship within independent variables mordant and exposure (light and laundering). Two-sample t test was performed to investigate the effect of a PAS mordant versus no mordant on overall color difference between specimens exposed to light and laundering. Findings indicated that dye absorption was improved with the use of a PAS mordant. For yarns premordanted with PAS the dyewood colors became warmer. A PAS mordant slightly improved colorfastness to light for black walnut and eastern redcedar, but did not influence Osage orange which had a color change from bright yellow to warm brown after exposure to light. Colorfastness to laundering improved only for Osage orange with a PAS mordant.
\end{abstract}

Keywords: Natural dyes, Mordant, Biomordant, Tannin, Potassium aluminum sulfate, Sustainability, Trees, Sawmill waste, Wool, Value-added

\section{Introduction}

Natural plant dyes and dyeing processes have the potential to impact the triple bottom line of niche markets in both positive and negative ways. The triple bottom line is a framework to measure environmental, social, and economic impacts on sustainability (Elkington 1998). Sustainability is defined as 'the principle ensuring that our actions today do not limit the range of economic, social, and environmental options open to future generations' (Elkington 1998, p. 20). Sustainably managed harvesting of dyestuffs provide a renewable, carbon reducing, biodegradable alternative agriculture product

(c) 2016 The Author(s). This article is distributed under the terms of the Creative Commons Attribution 4.0 International License (http://creativecommons.org/licenses/by/4.0/), which permits unrestricted use, distribution, and reproduction in any medium, provided you give appropriate credit to the original author(s) and the source, provide a link to the Creative Commons license, and indicate if changes were made. 
that employ local and rural communities (Saxena and Raja 2014). When not sustainably managed, communities can be economically exploited and natural environments devastated. Socially responsible dyeing practices maintain local and indigenous dye traditions, support the local economy, and create educational opportunities (Bebali Foundation 2013; Fletcher et al. 2012; Lopes Ferreira 2011). Beyond fiber dyeing, natural dyestuffs have market potential in the food, beverage, and cosmetic industries (Saxena and Raja 2014; Shahid and Mohammad 2013). Residual biomass on a small scale can be composted but can be a challenge for larger scale production (Saxena and Raja 2014). In addition, there is concern over the metallic mordant agent remaining in the effluent water as well as amounts of water and energy needed for the mordant and dye processes (Fletcher et al. 2012; Ismal et al. 2014).

A mordant is a substance that can form complexes between dye and fiber to increase affinity, substantivity, and fastness properties (Dean 2014; Haar et al. 2013; Prabhu and Bhute 2012). Potassium aluminum sulfate is the commonly used metallic mordant for protein fibers with aluminum acetate seeing increased use for cellulose fibers (Brown et al. 2010; Haar et al. 2013). The more toxic metallic mordants of copper, tin, and chrome are not typically used by today's craft and artisan dyer, yet these chemicals are still being included in some natural dye research. Natural or biomordants from aluminum accumulating plants and high tannin content plants are being explored as substitutes for the manufactured metallic mordants along with other alternative materials and methods (Cunningham et al. 2011; Flint 2001; Ismal et al. 2014; Kadolph and Casselman 2004; Vankar et al. 2008). Trees with high tannin content are often classified as a substantive dye which do not require a metallic mordant, but may also be used as a mordant depending on their tannin amount and chemical structure (Dean 2014; Ismal et al. 2014; Prabhu and Bhute 2012). However, the addition of an aluminum metallic mordant when dyeing with tree parts can improve colorfastness properties and shift color hue (Cardon 2007; Casselman 1993; Doty and Haar 2012).

The purpose of this research was to examine color properties of three regional dyewoods in the form of sawmill waste with and without a mordant treatment of potassium aluminum sulfate on wool yarn. The dyes were derived from Kansas black walnut (Juglans Nigra), Osage orange (Maclura pomifera), and eastern redcedar (Juniperus virginiana) and sourced from a sawmill in central Kansas, USA. Specifically, we analyzed the impact of an aluminum mordant use on dye concentration, hue, and colorfastness to light and laundering. Findings from the study will contribute to the understanding of sawmill waste as a dyestuff and use of an aluminum mordant with select sawmill waste, which may influence decision making for future research and dye practice by dye and handcraft artisans. Sawmill and timber owners can benefit economically as sawmill waste becomes a value-added product. Furthermore, this research contributes to the dialogue of how plant dyes can impact aspects of the triple bottom line in niche markets.

\section{Triple bottom line of natural dyeing}

The following is organized by environmental, social, and economic sustainability of wool fiber, mordant, and dyewood. While we recognize that the triple bottom line impacts are often inter-related, we have presented each separately for ease of organization. Further, 
due to trees and wool being natural products and limited research on social and economic values of natural dyeing, the environmental section is much longer.

\section{Environmental sustainability of natural dyes}

The environmental bottom line accounts for the sustainability of natural ecosystems through maintenance, renewal, reparability, or replacement (Elkington 1998). Careful consideration was taken when deciding upon the fiber, mordant, and dyes used in this study and how they affect the overall natural cycle. Wool was selected for this research due to its ability to absorb natural dyes and its renewable and biodegradable properties (Burgess 2011). Wool is considered a sustainable fiber that is grown on sheep and can be harvested without harm to the animal when ethical husbandry standards are met (Russell 2009). However, there is controversy over best practices to manage flystrike which until recently was commonly managed by skin removal (Sneddon and Rollin 2010). Wool fiber is used to make carpets, blankets, and garment textiles, it can be recycled into postconsumer products such as insulation and geotextiles, and later be fully composted back into the earth (Henry 2012; Russell 2009). Conversely, wool does have aspects that negatively affect environmental sustainability. Sheep, like all livestock, produce methane gas and require an extensive amount of land and water for nourishment (Henry 2012). Predatory animals frequently target sheep, causing ranchers to use a combination of lethal and nonlethal means to protect their investment (Sheep and Goats Death Loss 2010). This use of force by ranchers does correlate in many coyotes and wolves being exterminated from their native hunting areas (Fletcher et al. 2012). During processing, wool fiber requires water and energy to process the raw fiber into textiles and even more water will be required during the consumer use phase for wool garments (Henry 2012). Furthermore, wool textiles produce more methane during the disposal process when decomposing in a landfill, although it should be noted that all natural and synthetic fibers have this issue and that wool will decompose much faster than petroleum based fibers (Russell 2009).

The metallic mordant used in the study was potassium aluminum sulfate (PAS) crystals from Brenntag chemical distributor. According to the Safety Data Sheet provided by the distributor, PAS is considered non-hazardous and non-toxic to the environment when disposing by diluting with water and flushing in the sewer (Global Safety Management 2015). Even though PAS is used to purify water, there is environmental concern over disposal of mordant bath effluent into the sewer or land and scholars are thus exploring natural or biomordants as metallic mordant alternates with mixed results (Ismal et al. 2014; Vankar et al. 2008; Windholz 1983). Further, when mordanting is done separately from dyeing it does increase water and thermal energy usage. Reuse and replenishing the mordant bath can assist with this concern.

Sawmill waste from Kansas black walnut, Osage orange, and eastern redcedar timber were the dyestuffs used in this study. Natural dyers have long used numerous parts of trees (leaf, fruit, bark, root, and sawdust) for dye color due to their tannin content which can act as a dye or mordant, particularly on cotton (Cardon 2007; Prabhu and Bhute 2012; Seth 2003). This use of varying parts of the tree as a dyestuff calls into question its sustainability as an ongoing and viable product. The fruit of trees could be considered the most sustainable, with new produce grown each year as well as being value-added, 
since the parts of the fruit that give the best color are usually inedible (e.g., black walnut hulls and pomegranate rinds). Collecting fallen leaves and branches is another sustainable approach as long as there is enough windfall left behind for insect and wildlife biodiversity. Less sustainable would be the bark, roots, and heartwood of a tree. While it's possible to collect roots and bark from trees without harming the plant, it does take skill and knowledge of a tree's structural and nutritional needs and thus is not recommended. A healthier practice would be to collect these items from trees already being harvested for manufacturing or for timber control as was done in this study.

Natural dyes from trees pose interesting positive characteristics as a colorant, due to their ability to produce a naturally occurring mordant called tannic acid which protects the tree from various infectious microorganisms and prevents rotting (Hon and Shiraishi 2000). While many tannins give a brown cast to the dye color, some research suggests that tannin mordants and dyes may darken dyed textiles as they age, instead of the color fading due to exposure to washing and light (Cardon 2007; Richards and Tyrl 2005). Furthermore, previous research found that wool and cotton with a PAS mordant and dyed with a tannin dye (i.e., black walnut bark and hulls) had improved colorfastness to light and laundering (Doty and Haar 2012; Mirjalili and Karimi 2013; Sharma and Grover 2011). Tannin amounts vary greatly between tree species and then amounts can vary within a single tree depending on the time of year, age, moisture, temperature, and soil condition (Flint 2001; Pizzi et al. 1986). As a general rule, hardwoods contain higher tannin amounts than softwoods (Pizzi et al. 1986). Information regarding the amounts of tannin in black walnut, Osage orange, and eastern redcedar was hard to obtain. However, recent research looking at the discoloration of hardwoods suggests that black walnut heartwood contains $2 \%$ tannin (Hon and Shiraishi 2000). While data from hide tanning research performed in the 1910s suggests that Osage orange native to Texas had upward of 10-11 \% tannin (Kressman 1916). Research performed in 1901 by the pharmaceutical industry suggests tannin amounts in eastern redcedar at 2-8 \% depending on the time of year when samples were collected (Peacock 1901). Naturally occurring tannin in dyewood could possibly make for dyes that are durable without the aid of a mordant which in turn could mean less effluents, even ones considered nontoxic, being disposed into the environment following mordanting.

Two of the three dyewoods used in this study, eastern redcedar and Osage orange, were selected due to their status as an invasive species. Eastern redcedar had an increase in stock volume of 23,000 \% on surveyed Kansas lands from 1965 to 2005, effectively decreasing the value of undermanaged pastureland (Moser et al. 2008). Once planted for its excellent properties as a living fence line, the Osage orange can be a nuisance to cattlemen as they tend to invade pastureland (Rutter 2013). Even though Osage orange and eastern redcedar are currently invasive, this status would need to be monitored to ensure environmentally balanced harvesting.

\section{Social sustainability of natural dyes}

The social bottom line encompasses social, ethical, and cultural issues of humans in the form of public health, skills, and education, as well as a society's health and wealthcreation potential (Elkington 1998). Fletcher et al. (2012) state that from fiber through dyeing, the worker's health, safety, and exposure to toxins should be assessed, as well as 
fair labor practices. As with environmental sustainability, there is health concern over chemical exposure and disposal of metallic mordant effluent (Ismal et al. 2014; Vankar et al. 2008). The PAS crystals used in the study were rated as no significant risk to health, while ScienceLab.com rated aluminum potassium sulfate as a moderate health risk in case of ingestion, inhalation, and irritant to skin and eye (Aluminum potassium sulfate 2013; Global Safety Management 2015). As when working with any fine particle, proper ventilation and protective glasses, gloves, and clothing are recommended. Naturally dyed textiles are generally considered safe for the wearer, however they can also impart positive finishing properties that are antimicrobial, insect repelling, deodorizing, and UV-protective (Shahid and Mohammad 2013). Social responsibility was an overarching theme of many of the presentations at the International Symposium and Exhibition of Natural Dyes (2011), attended by one of the authors. The aims of Etno Botantica serve to exemplify social, environmental, and economic efforts of natural dye groups represented at the conference:

The program ETNO BOTANICA-natural dyes aims to contribute to the economic sustainability of the native communities in the Amazonian rainforest and to family organic farming, preserving the local culture, protecting their rights over their knowledge, maintaining the existing biodiversity in their territories, as legitimate cultural heritage for future generations. The entire line of products and services ETNO BOTANICA is based on principles of social and environmental responsibility. The plant colorant extracts come from farming or extractive activities sustained among local communities. The clean production process doesn't generate toxic waste, provides improved quality of life for producers and creates an alternative for the conscious consumer (Lopes Ferreira 2011, p. 67).

Littrell and Dickson (1999) recognize the role of Alternative Trade Organizations (ATO) in the social development and economic success of impoverished artisans in developing countries, where natural dyeing may be included in the product development process. Based on their extensive research, a fair trade model was developed encompassing ATO core requirements, market objectives from artisan to consumer, primary activities, and skill requirements resulting in measureable direct outcomes. Such a framework may be of benefit to future research measuring the social impact of natural dyes.

\section{Economic sustainability of natural dyes}

The economic bottom line is the value of financial, physical, and human capital, as well as the economic benefit to the surrounding community and society (Elkington 1998). The growth and maintenance of black walnut trees are encouraged in Kansas as a cash crop, due to both a desirability as a hard wood and an edible fruit (Moser et al. 2008). Whether dyewoods are harvested due to the maintenance of pastureland or because of economic significance, sawmill waste from their timber could be a sustainable color source for textiles while adding value to a local byproduct. Using byproducts and waste from agriculture, forestry, and the food industry as natural dyes, may lower costs of natural dye production while consuming another industry's waste (Shahid and Mohammad 2013). Dye waste pulp from the Indian Trapa fruit skin was effective in absorbing chromium contaminated groundwater (Vankar et al. 2008). Mill waste from manufacturing 
have traditional uses such as paper products, particle board, and mulch but have been further explored for less conventional projects such as bio-oil, making bricks, and as an absorbent for water pollutants (Falk 1997; Crini 2006; Turgut and Algin 2007; Rout et al. 2009). Despite these varied uses wood products are often sent to the landfill or combusted for energy and fail to contribute any added value to their life cycle (Puettmann and Wilson 2007). Other markets and applications for natural dyes include colorant for cosmetics, food, beverage, hair, leather, paint, lacquers, and ink (International Symposium and Exhibition of Natural Dyes 2011; Shahid and Mohammad 2013).

Crop production of plant dyes for research, development, and large scale production has potential to economically benefit communities if sustainably managed as with Centre of Research, Innovation and Technology Transfer in Horticulture (CRITT Horticole), France. For 25 years CRITT Horticole and offshoot company Couleurs de Plantes (since 2005), has conducted research and development of plant colorants, resulting in cultivation and production of extracts and pigments on an industrial scale (Brenac 2011). Some other large scale production companies are Bleu de Pastel de Lectoure in France, Be Be Cotton Knitting in Republic of China-Taiwan, Aura Herbal Textiles in India, Woad Centre in Britain, and PAI Natural Color in Italy. Research efforts to reduce overall processing costs, energy consumption, and waste pollution through sonication methods in place of traditional thermal methods are reported by Shahid and Mohammad (2013).

\section{Methods}

Black walnut, Osage orange, and eastern redcedar mill waste was sourced from a privately owned sawmill located near Galva, Kansas, USA. Millings from this location contained all portions of the dye's respective tree trunk (i.e., bark, phloem, cambium, sapwood, heartwood, and pith). It cannot be determined as to the year or season when the trees were felled or milled. The chemical compounds of trees that produce their unique colors have not been identified. However, tannic acid present in those trees can help dyeing the protein fibers. As the tannic acid is a weak acid, amino acids of the protein fibers would favor the protonated form in the acidic condition, and this might lead to the facilitated chemical bonding with the color-producing chemical compounds. The wool yarn was 30/2 worsted (style \# SK $2 / 30$ at owf of $5 \mathrm{~g}$ ) from Testfabrics. Inc. All aqueous solutions were at a ratio of 80:1 (liquor to weight-of-goods) using reverse osmosis water. Scouring soap was Orvus ${ }^{\circledR}$ paste (Dover Saddlery) at $2 \%$ owf and the PAS crystal (Brenntag) mordant solution was $12 \%$ owf. Follows is an abbreviated presentation of the pre-test, scouring, mordanting, and dyeing procedures; detailed procedures are presented by Doty (2015).

Tinctorial strengths differ between tree species and mordant treatment, resulting in varied color depth and colorfastness properties when used at equal concentrations. Pretesting determined dyewood concentration required for PAS mordanted and nonmordanted fibers to produce visually comparable depth of shade according to the American Association of Textile Colorist and Chemists (AATCC) standard depth scales (AATCC 2009). See Table 1. All test samples were scoured, then half of the samples were randomly assigned to one of three mordant bath treatments all with PAS at $12 \%$ owf. For each dyewood, three mordanted and three nonmordanted samples were randomly assigned to one of six dye baths and dyed using the predetermined concentrations 
Table 1 Dyewood concentrations and standard depth of shade to achieve comparable color depth between potassium aluminum sulfate (PAS) mordanted and nonmordanted wool yarn

\begin{tabular}{lll}
\hline Dyewood and mordant type & Concentration to owf (\%) & Standard depth \\
\hline $\begin{array}{l}\text { Black walnut } \\
\text { PAS mordant }\end{array}$ & 100 & $1 / 12$ \\
$\begin{array}{l}\text { Black Walnut } \\
\text { No mordant }\end{array}$ & 200 & $1 / 12$ \\
$\begin{array}{l}\text { Osage orange } \\
\text { PAS mordant }\end{array}$ & 40 & $1 / 1$ \\
$\begin{array}{l}\text { Osage orange } \\
\text { No mordant }\end{array}$ & 50 & $1 / 1$ \\
Eastern redcedar & 100 & $1 / 25$ \\
PAS mordant & 150 & $1 / 25$ \\
Eastern redcedar & & \\
No mordant & & .
\end{tabular}

The depth of shade scale consists of six designations; there is "standard depth" at 1/1, "double depth" at 2/1 that is darker than standard depth, and fractional depths with $1 / 3,1 / 6,1 / 12$ and 1/25 that are lighter than standard depth, with 1/25 being the lightest

(Table 1). Scouring, mordanting, and dyeing was conducted using an Atlas LaunderOmeter in order to maintain temperature and agitation.

Dyed specimens were subjected to tests for colorfastness to laundering and light according to AATCC Test Method 61-2007 Colorfastness to Laundering: Accelerated, Test No. 1A and AATCC Test Method 16-2004 Colorfastness to Light, Option 3 (AATCC 2009). Laundering was conducted using an Atlas Launder-Ometer which simulated five hand launderings at low temperature $\left(40 \pm 3{ }^{\circ} \mathrm{C}\right)$ using individual stainless steel canisters. Light testing was conducted by Atlas Weathering Company using an Atlas Xenon Weather-Ometer, which determined fading after exposure to 20 AATCC fading units (AFU) or approximately 21.5 h (AATCC 2009).

Prior to and following exposure to laundering and light, CIELab ratings were taken, determining the specific color parameters lightness $\left(L^{*}\right)$, greenness-redness $\left(a^{*}\right)$, and blueness-yellowness $\left(b^{*}\right)$ (Tables 2, 3). A RM200QC Imagining Spectrocolormeter (X-Rite, Michigan, USA) was used to obtain CIELab ratings. According to Marcus (1998), ratings indicate for $L^{*}$ the higher the number the lighter the color, with black at 0 and white at 100 . For coordinate $\mathrm{a}^{*}$, red is $+\mathrm{a}^{*}$ and green is $-\mathrm{a}^{*}$; for coordinate $\mathrm{b}^{*}$, yellow is indicated by $+b^{* *}$ and blue is indicated by $-b^{*}$.

Descriptive statistics (mean and standard deviation) for $L^{*} a^{*} b^{*}$ coordinates were used to examine the directional relationship within the independent variables mordant and exposure (light and laundering). Two-sample t test was performed to investigate the effect of a PAS mordant versus no mordant on overall color difference between specimens exposed to light and laundering, where the overall color difference $\Delta \mathrm{E}$ was calculated by:

$$
\Delta \mathrm{E}=\sqrt{\left(L_{1}-L_{2}\right)^{2}+\left(a_{1}-a_{2}\right)^{2}+\left(b_{1}-b_{2}\right)^{2}} .
$$

$\mathrm{L}_{1}: L^{\prime}$ value of exposed specimen, $\mathrm{L}_{2}: L^{\prime}$ value of unexposed specimen, $\mathrm{a}_{1}: a^{\prime}$ value of exposed specimen, $\mathrm{a}_{2}: a^{\prime}$ value of unexposed specimen, $\mathrm{b}_{1}: b^{\prime}$ value of exposed specimen, $\mathrm{b}_{2}: b^{\prime}$ value of unexposed specimen. 
Table 2 Descriptive statistics for $L^{*} a^{*} b^{*}$ coordinates of unexposed standards and specimens exposed to colorfastness to light testing

\begin{tabular}{|c|c|c|c|c|c|}
\hline Dye/mordant & $\begin{array}{l}\text { Standard/exposed } \\
\text { to light }\end{array}$ & $\begin{array}{l}L \\
\text { Mean (SD) }\end{array}$ & $\begin{array}{l}a \\
\text { Mean (SD) }\end{array}$ & $\begin{array}{l}b \\
\text { Mean (SD) }\end{array}$ & Color swatch \\
\hline $\begin{array}{l}\text { Black walnut } \\
\text { PAS mordant }\end{array}$ & Standard & $61.32(0.96)$ & $11.59(0.46)$ & $24.70(0.71)$ & \\
\hline $\begin{array}{l}\text { Black walnut } \\
\text { PAS mordant }\end{array}$ & Exposed to light & $65.06(1.17)$ & $11.66(0.56)$ & $25.64(0.88)$ & \\
\hline $\begin{array}{l}\text { Black walnut } \\
\text { No mordant }\end{array}$ & Standard & $57.59(1.43)$ & $10.49(0.50)$ & $22.12(1.25)$ & \\
\hline $\begin{array}{l}\text { Black walnut } \\
\text { No mordant }\end{array}$ & Exposed to light & $62.54(1.31)$ & $10.59(0.36)$ & $23.43(0.61)$ & \\
\hline $\begin{array}{l}\text { Osage orange } \\
\text { PAS mordant }\end{array}$ & Standard & $69.49(1.52)$ & $8.37(0.60)$ & $56.03(1.79)$ & \\
\hline $\begin{array}{l}\text { Osage orange } \\
\text { PAS mordant }\end{array}$ & Exposed to light & $63.96(1.11)$ & $10.12(0.26)$ & $45.90(1.06)$ & \\
\hline $\begin{array}{l}\text { Osage orange } \\
\text { No mordant }\end{array}$ & Standard & $70.40(1.67)$ & $6.24(0.39)$ & $45.02(1.76)$ & \\
\hline $\begin{array}{l}\text { Osage orange } \\
\text { No mordant }\end{array}$ & Exposed to light & $63.66(0.84)$ & $10.24(0.34)$ & $35.29(0.98)$ & \\
\hline $\begin{array}{l}\text { Eastern redcedar } \\
\text { PAS mordant }\end{array}$ & Standard & $73.87(1.39)$ & $7.98(0.19)$ & $24.77(0.74)$ & \\
\hline $\begin{array}{l}\text { Eastern redcedar } \\
\text { PAS mordant }\end{array}$ & Exposed to light & $79.21(0.95)$ & $6.20(0.49)$ & $24.46(0.87)$ & \\
\hline $\begin{array}{l}\text { Eastern redcedar } \\
\text { No mordant }\end{array}$ & Standard & $71.06(1.19)$ & $9.08(0.38)$ & $14.93(0.78)$ & \\
\hline $\begin{array}{l}\text { Eastern redcedar } \\
\text { No mordant }\end{array}$ & Exposed to light & $75.93(0.91)$ & $6.37(0.25)$ & $18.22(0.38)$ & \\
\hline
\end{tabular}

Color swatches were generated with $\mathrm{L}^{*}$ (lightness), $\mathrm{a}^{*}$ (greenness-redness), $\mathrm{b}^{*}$ (blueness-yellowness) rounded to the nearest whole number using http://www.workwithcolor.com/color-converter-01.htm. The standard and specimens were $100 \%$ wool yarn. Potassium aluminum sulfate (PAS) was the mordant 
Table 3 Descriptive statistics for $L^{*} a^{*} b^{*}$ coordinates of unexposed standards and specimens exposed to colorfastness to laundering testing

\begin{tabular}{|c|c|c|c|c|c|}
\hline Dye/mordant & $\begin{array}{l}\text { Standard/exposed to } \\
\text { laundering }\end{array}$ & $\begin{array}{l}L \\
\text { Mean (SD) }\end{array}$ & $\begin{array}{l}a \\
\text { Mean (SD) }\end{array}$ & $\begin{array}{l}\boldsymbol{b} \\
\text { Mean (SD) }\end{array}$ & Color swatch \\
\hline $\begin{array}{l}\text { Black walnut } \\
\text { PAS mordant }\end{array}$ & Standard & $61.32(0.96)$ & $11.59(0.46)$ & $24.70(0.71)$ & \\
\hline $\begin{array}{l}\text { Black walnut } \\
\text { PAS mordant }\end{array}$ & Exposed to laundering & $60.01(0.69)$ & $10.43(0.36)$ & $20.50(0.47)$ & \\
\hline $\begin{array}{l}\text { Black walnut } \\
\text { No Mordant }\end{array}$ & Standard & $57.59(1.43)$ & $10.49(0.50)$ & $22.12(1.25)$ & \\
\hline $\begin{array}{l}\text { Black Walnut } \\
\text { No mordant }\end{array}$ & Exposed to laundering & $58.30(0.97)$ & $9.20(0.39)$ & $20.20(0.44)$ & \\
\hline $\begin{array}{l}\text { Osage orange } \\
\text { PAS mordant }\end{array}$ & Standard & $69.49(1.52)$ & $8.37(0.60)$ & $56.03(1.79)$ & \\
\hline $\begin{array}{l}\text { Osage orange } \\
\text { PAS mordant }\end{array}$ & Exposed to laundering & $72.06(1.04)$ & $7.03(0.82)$ & $58.70(1.54)$ & \\
\hline $\begin{array}{l}\text { Osage orange } \\
\text { No mordant }\end{array}$ & Standard & $70.40(1.67)$ & $6.24(0.39)$ & $45.02(1.76)$ & \\
\hline $\begin{array}{l}\text { Osage orange } \\
\text { No mordant }\end{array}$ & Exposed to laundering & $68.88(0.52)$ & $7.26(0.49)$ & $39.81(0.63)$ & \\
\hline $\begin{array}{l}\text { Eastern redcedar } \\
\text { PAS mordant }\end{array}$ & Standard & $73.87(1.39)$ & $7.98(0.19)$ & $24.77(0.74)$ & \\
\hline $\begin{array}{l}\text { Eastern redcedar } \\
\text { PAS mordant }\end{array}$ & Exposed to laundering & $71.33(0.88)$ & $10.04(0.39)$ & $23.02(0.66)$ & \\
\hline $\begin{array}{l}\text { Eastern redcedar } \\
\text { No mordant }\end{array}$ & Standard & $71.06(1.19)$ & $9.08(0.38)$ & $14.93(0.78)$ & \\
\hline $\begin{array}{l}\text { Eastern redcedar } \\
\text { No mordant }\end{array}$ & Exposed to laundering & $70.82(1.38)$ & $9.29(0.43)$ & $12.99(0.50)$ & \\
\hline
\end{tabular}

Color swatches were generated with $\mathrm{L}^{*}$ (lightness), $\mathrm{a}^{*}$ (greenness-redness), $\mathrm{b}^{*}$ (blueness-yellowness) rounded to the nearest whole number using http://www.workwithcolor.com/color-converter-01.htm. The standard and specimens were $100 \%$ wool yarn. Potassium aluminum sulfate (PAS) was the mordant 


\section{Results and discussion}

\section{Dye concentration}

Black Walnut had a standard depth of $1 / 12$ and required twice as much mill waste for nonmordanted (200\% owf) compared to PAS mordanted wool yarns (100\% owf). See Table 1 . Osage orange gave a standard depth at $1 / 1$ using $50 \%$ owf for nonmordanted and $40 \%$ owf for mordanted. Eastern redcedar had the lowest (i.e., lightest) depth shade at $1 / 25$ standard depth with $150 \%$ owf for nonmordanted and $100 \%$ owf for mordanted yarn. In summary, yarns premordanted with $12 \%$ PAS and dyed with black walnut, Osage orange, and eastern redcedar required less dye than nonmordanted yarns to achieve a comparable depth of shade. The effect was greater for black walnut and eastern redcedar, requiring 100 and $150 \%$ more dyestuff respectively for nonmordanted yarns to obtain similar depth of shade compared with mordanted yarns.

\section{Dye concentration and the triple bottom line}

The higher dyewood concentrations required of nonmordanted yarn to achieve comparable depth of shade as the PAS mordanted yarn indicate that a PAS mordant treatment enhanced dye adhesion thus requiring much less dyewood for black walnut and eastern redcedar. Even though Osage orange had comparatively less difference between PAS mordant and no mordant, $10 \%$ is still considerable for natural dyes that will quantify quickly when dyeing large amounts. This finding impacts the environmental bottom line as trees are a natural resource that are slow to replenish. In addition, using less sawmill waste means less biomass remaining after dye extraction that needs disposal or combustion. While not as problematic to the craft dyer who can add it to the compost pile or garden, it may impact large scale dyers. However, these larger scale dyers could yet again find a use for the sawmill waste and have it made into paper products, particle board, or mulch. Socially, there are concerns over the use of manufactured metallic mordants which may impact health if proper ventilation, protection, and disposal is not practiced. Conversely, the use of less dyestuff with aid of a metallic mordant would help maintain local biodiversity and perhaps cultural heritage as there would be less need to cut down vegetation for dyeing. The need for less dyewood with use of a PAS mordant increases the already economic efficient use of sawmill waste and invasive tree species as dyestuffs. The use of a mordant would add its cost along with the addition of the mordant treatment step which uses water and thermal energy.

\section{Color composition}

Descriptive statistics (mean and standard deviation) for $L * a^{*} b *$ coordinates were used to examine the directional relationship within the independent variables mordant and exposure. Assessing this information allowed us to compare overall color change due to the use of a PAS mordant. The PAS mordant influenced the color cast of wool yarns dyed with black walnut, Osage orange, and eastern redcedar regardless of light exposure or laundering (Tables 2, 3). For black walnut, mordanted specimens were considerably lighter, redder $\left(a^{*}\right)$ and yellower $\left(b^{*}\right)$ than nonmordanted. For Osage orange mordanted specimens were yellower $\left(b^{*}\right)$ than nonmordanted. For eastern redcedar, mordanted specimens were lighter, greener $\left(a^{*}\right)$ and yellower $\left(b^{*}\right)$ than nonmordanted. 


\section{Exposure to light}

When looking at the independent variable exposure, all dyes had considerable effect for $L^{*}$ (lightness) when exposed to $21.5 \mathrm{~h}$ of light (Table 2). For black walnut, both mordanted and nonmordanted specimens turned lighter and bluer (decrease in $b^{*}$ ) after exposure to light. For Osage orange dyed yarns, the color turned darker (lowered $L^{*}$ ) both for mordanted and nonmordanted specimens after being exposed to light. This finding while unusual was not surprising as Osage orange is known to darken over time (Cardon 2007; Richards and Tyrl 2005). Eastern redcedar dyed mordanted and nonmordanted yarns turned lighter after exposure to light, and nonmordanted specimens turned yellower while mordanted specimens showed little changes of $b^{*}$. For eastern redcedar, mordanted yarns have a slight yellow cast (light tan color) and the nonmordanted yarns a slight red cast (light pink mauve color). It is recommended for natural dyers to use a PAS mordant if they want to shift the color of eastern redcedar from pink to tan. However, the pink color of nonmordanted yarn may fade towards tan due to exposure to light, so dyers should protect any project they want to remain pink from exposure.

For the independent variable Mordant, the PAS mordant influenced the color compositions of wool yarns dyed with black walnut, Osage orange, and eastern redcedar prior to and following exposure to light. While all three mordanted dyewood yarns had warmer (yellower and/or redder) tones prior to light exposure compared with nonmordanted yarns, eastern redcedar was both yellower and greener prior to exposure.

\section{Exposure to laundering}

When examining the independent variable Exposure, laundering had a different influence than light exposure on color compositions of mordanted and nonmordanted dyed specimens. For black walnut, mordanted and nonmordanted specimens were greener $\left(a^{*}\right)$ and bluer $\left(b^{*}\right)$ when subjected to laundering (Table 3). Mordanted specimens were yellower $\left(b^{*}\right)$ than nonmordanted specimens but only before laundering. After laundering, $b^{*}$ value became similar for both mordanted and nonmordanted. For Osage orange, mordanted specimens were redder $\left(a^{*}\right)$ than nonmordanted before laundering, but $a^{*}$ of both became similar after laundering. Mordanted Osage orange was also yellower $\left(b^{*}\right)$ and nonmordanted Osage orange was bluer $\left(b^{*}\right)$ after laundering. For eastern redcedar, specimens turned lighter, redder, and bluer after laundering both for mordanted and nonmordanted. When visually inspecting the specimens, mordanted and laundered Osage orange was a brighter and clearer yellow when compared to nonmordanted. It is recommended for natural dyers wanting to maintain a bright yellow to use a PAS mordant on wool yarns dyed with Osage orange.

When examining the independent variable Mordant for PAS mordanted and laundered yarns dyed with black walnut, Osage orange, and eastern redcedar they were warmer (redder and/or yellower) than nonmordanted yarns, supporting previous research that the use of a PAS mordant changes the color of natural dyes towards warmer (Doty and Haar 2012; Haar et al. 2013).

In summary, the PAS mordant influenced the color cast subtly of the selected dyewoods before and after exposure to light and laundering. For black walnut, the mordant had a warming effect that remained after exposure to light, but not after laundering. Osage orange was also warmer with the mordant, but the shift was not maintained after 
exposure to light and laundering. The mordant had a yellowing effect on eastern redcedar that became similar to nonmordanted with exposure to light but remained after laundering.

\section{Color composition and the triple bottom line}

The PAS mordant influenced color cast, however dependent upon the dye, the shift may or not remain after exposure to light and laundering. In addition, when visually comparing resulting color, the difference may not be enough to warrant the use of a PAS for color changing purposes. Elimination of the metallic mordant brings environmental value by reduction of water, thermal energy, and mordant disposal. As well as social health value, by reducing potential exposure of fine particles. Alternatively, there is social value in understanding the subtle influence of PAS on colorcast following dyeing and exposure to light and laundry which contributes to the dyer's overall knowledge and color expectancy from natural dyes. Which in turn may influence economic value by providing a product that addresses consumer expectations for color consistency.

\section{Colorfastness properties}

Overall color difference of PAS mordanted and nonmordanted specimens were assessed using $\Delta \mathrm{E}$ before and after (1) exposure to light, and (2) laundering (Table 4). Smaller $\Delta$ $E$ means less color change after exposure to light and laundering, which could be interpreted as better colorfastness.

\section{Exposure to light}

For yarns dyed with black walnut and exposed to light, two-sample $t$ test showed that there is a significant effect $\left(\mathrm{t}_{(16)}=2.01, \mathrm{p}=0.061\right)$ of mordant treatment on the colorfastness to light (mordanted $\Delta \mathrm{E}=3.95$ and nonmordanted $\Delta \mathrm{E}=5.17$ ), suggesting that PAS mordanted yarn showed less color change after exposure to light than nonmordanted yarns (Table 4). For Osage orange yarns exposed to light, $t$ test suggested no significant effect $\left(\mathrm{t}_{(16)}=1.38, \mathrm{p}=0.187\right)$ of mordant treatment (mordanted $\Delta \mathrm{E}=11.70$

Table 4 Two-sample $t$ test results of mordant type for colorfastness to light and laundering on dyed wool yarn: colorfastness is indicated in terms of color difference $\Delta E$ of samples before and after light or laundering exposure

\begin{tabular}{|c|c|c|c|c|c|}
\hline & \multicolumn{2}{|c|}{ Nonmordanted } & \multicolumn{2}{|c|}{ Mordanted } & \multirow[t]{2}{*}{ t value } \\
\hline & $M$ & SD & M & SD & \\
\hline \multicolumn{6}{|l|}{ Exposure to light } \\
\hline Black walnut & 5.17 & 1.31 & 3.95 & 1.25 & $2.01^{*}$ \\
\hline Osage orange & 12.52 & 1.14 & 11.70 & 1.35 & 1.38 \\
\hline Eastern redcedar & 6.51 & 0.72 & 5.72 & 0.95 & $1.99^{*}$ \\
\hline \multicolumn{6}{|c|}{ Exposure to laundering } \\
\hline Black walnut & 2.56 & 0.71 & 4.61 & 0.50 & $-7.09^{* * *}$ \\
\hline Osage orange & 5.57 & 0.57 & 4.26 & 1.07 & $3.25^{* *}$ \\
\hline Eastern redcedar & 2.35 & 0.70 & 3.83 & 0.60 & $-4.80^{* * *}$ \\
\hline
\end{tabular}

${ }^{*} p<0.05$

** $p<0.01$

$* * * p<0.001$ 
and nonmordanted $\Delta \mathrm{E}=12.52$ ) conditions. For yarns exposed to light and dyed with eastern redcedar, there was significant effect of mordant treatment on colorfastness to light such that mordanted $(\Delta \mathrm{E}=5.72)$ yarns had less color change than nonmordanted $(\Delta \mathrm{E}=6.51)$ conditions; $\mathrm{t}_{(16)}=1.99, \mathrm{p}=0.064$.

\section{Exposure to laundering}

For yarns dyed with black walnut and laundered, $\mathrm{t}$ test showed a significant effect $\left(\mathrm{t}_{(16)}=-7.09, \mathrm{p}=0.000\right)$ of mordant treatment on the colorfastness to laundering, suggesting that nonmordanted $(\Delta \mathrm{E}=2.56$ ) yarns outperformed (i.e., had less color change) mordanted $(\Delta \mathrm{E}=4.61)$ (Table 4$)$. For yarns dyed with Osage orange and exposed to laundering, $\mathrm{t}$ tests indicated significant difference $\left(\mathrm{t}_{(16)}=3.25, \mathrm{p}=0.005\right)$ that mordanted $(\Delta \mathrm{E}=4.26)$ yarns had less color change than nonmordanted $(\Delta \mathrm{E}=5.569)$ conditions. For eastern redcedar yarns exposed to laundering, the difference between mordanted and nonmordanted was significant such that nonmordanted $(\Delta \mathrm{E}=2.35)$ yarns had improved colorfastness to laundering over mordanted $(\Delta \mathrm{E}=3.83)$ conditions; $\mathrm{t}_{(16)}=-4.80, \mathrm{p}=0.000$.

In summary, mordanted black walnut and eastern redcedar dyed wool yarn had less color change compared to no mordant for colorfastness to light, while colorfastness to laundering had less change for nonmordanted. These findings are similar to prior research with black walnut bark dyed on wool gabardine fabric where mordanted had improved lightfastness with no difference between mordant treatment for exposure to laundering (Doty and Haar 2012). Colorfastness to laundering results for Osage orange indicated mordanted had less color change than nonmordanted, however exposed yarns were significantly darker instead of the more typical lightening of hue. While colorfastness to light for Osage orange was not significantly different, the overall color change was also slightly darker. This finding while unusual was not surprising as Osage orange is known to darken over time (Cardon 2007; Richards and Tyrl 2005).

\section{Colorfastness and the triple bottom line}

Overall, colorfastness to light and laundering findings indicate mixed results for color change when using a PAS mordant for the selected mill waste, however any improvement to colorfastness is considered positive. Thus, using a PAS mordant may be preferable as lightfastness improved for black walnut and eastern redcedar, while washfastness improved for Osage orange. Improved colorfastness properties may enhance sell-ability of dyed products as consumer concern for color longevity is addressed. Environmentally and economically, the use of a premordant does increase cost and the amount of time, water, and thermal energy required. Future studies could evaluate adding the mordant to the dye bath, instead of as a pretreatment. As noted prior, there is growing concern over disposal of any residual manufactured metallic mordant and its impact on the environment and community health. As we did not measure the amount of remaining PAS mordant from a $12 \%$ owf mordant bath, we cannot provide insight to this concern. A possible social impact of introducing use of a PAS mordant is that such practice may not be conducive to long standing natural dye traditions and if accepted could change a cultural heritage. 


\section{Conclusions}

Findings from this study indicate that use of a PAS mordant does influence dye concentration, hue, and colorfastness to light and laundering of sawmill waste dyed wool yarn with implications for the triple bottom line. Perhaps the most important finding is that the PAS mordant decreased the amount of sawmill waste dyestuff by $10-150 \%$ to achieve expected color depth. As trees are slow to replenish, using less and using an existing timber byproduct as dyestuff has environmental and economic value. Using invasive tree species also helps the environment by assisting to balance prairie and pastureland ecosystems.

The influence of PAS on hue and colorfastness had mixed results. The PAS mordant had a warming effect on all of the dyewoods that was minimized for black walnut after laundering, while eastern redcedar's cast was reduced after light exposure. Regardless of mordant type, Osage orange darkened from a golden yellow to a tan/brown following exposure to light. Colorfastness to light was enhanced with a PAS mordant for black walnut and eastern redcedar, while Osage orange had a significant difference from laundering but not for light. While any improvement to colorfastness is viewed as positive, the mixed results and subtle overall visual color difference from mordant use may not be enough to convince dyers to use a metallic mordant with tannin dyestuffs. The use of a mordant does mean another step in the dyeing process that uses water, energy, and may release unbound mordant chemicals into disposal systems, impacting both the environment and health of communities. Further, introduction of metallic mordant use may impact the cultural heritage of traditional dye practices. Conversely, understanding and utilizing a metallic mordant to shift color, improve lightfastness, and understand long term color results may create social value through new knowledge, as well as economic gain by addressing consumer concern over colorfastness of natural dyes.

This study did not measure tannin concentration of the sawmill waste nor amount of PAS in the residual mordant solution. Measuring tannin amounts in future studies will provide difficult to find tannin information on regional dyewoods and assist in understanding the role of tannin in interpreting colorfastness data. Future analysis of the chemical composition of pre- and post-mordant solution will provide data on the actual amount of PAS remaining in the waste water and thus assist in understanding of the environmental impact of a manufactured metallic aluminum mordant. Finally, there is a need to better understand social impacts of natural dyes upon the dynamics, health, knowledge, and wealth creation for families, communities, and cultural traditions.

Authors' contributions

KD designed the study, carried out the acquisition of data, and participated in the statistical analysis, and the construction and editing of the manuscript. SH participated in the design of the study, acquisition of data, and the construction and editing of the manuscript. JK participated in the statistical analysis and editing of the manuscript. All authors have read and approved the final manuscript.

Author details

${ }^{1}$ Cornell University, Ithaca, NY, USA. ${ }^{2}$ Kansas State University, Manhattan, KS 66506, USA.

Competing interests

The authors declare that they have no competing interests. 


\section{References}

Aluminum potassium sulfate material safety data sheet. (2013). http://www.sciencelab.com/search.php?q=potassium+alu minum + sulfate\&btnSearch $=+$ Search + .

American Association of Textile Chemists and Colorists. (2009). 2009 technical manual of the American Association of Textile Chemists and Colorists (Vol. 84). Durham: AATCC.

Bebali Foundation. (2013). The plant mordant project. http://plantmordant.org/symplocos/.

Brenac, P. (2011). Natural colors for green products: Advances on industrial production, quality, markets. Paper presented at the meeting of International Symposium and Exhibition of Natural Dyes, La Rochelle, France. http://www.tcfdatu. org/files/Isend2011Proceedings.pdf.

Brown, D., de Souza, D., \& Ellis, C. (2010). How to mordant cotton-let me count the ways. Turkey Red Journal, 15(2). http:// turkeyredjournal.com/archives/N15 12/DeSouza.html.

Burgess, R. (2011). Harvesting color: How to find plants and make natural dyes. New York: Artisan Books.

Cardon, D. (2007). Natural dyes: Sources, tradition, technology and science. London: Archetype.

Casselman, K. L. (1993). Craft of the dyer: Colour from plants and lichens of the Northeast. Toronto: University of Toronto Press.

Crini, G. (2006). Non-conventional low-cost adsorbents for dye removal: A review. Bioresource Technology, 97(9), 1061-1085.

Cunningham, A. B., Maduarta, I. M., Howe, J., Ingram, W., \& Jansen, S. (2011). Hanging by a thread: Natural metallic mordant processes in traditional Indonesian textiles. Economic Botany, 65(3), 241-259.

Dean, J. (2014). A heritage of colour: Natural dyes past and present. Kent: Search Press Limited.

Doty, K. (2015). Comparison of aluminum mordanted and nonmordanted wool yarns naturally dyed with Kansas black walnut, Osage orange, and Eastern redcedar sawdust (Master's Thesis). Kansas: Kansas State University. http://www.hdl. handle.net/2097/20373.

Doty, K., \& Haar, S. (2012). Comparison of aluminum mordanted and nonmordanted wool and cotton dyed with walnut. Proceedings of the International Textile and Apparel Association. http://cdm16001.contentdm.oclc.org/cdm/ compoundobject/collection/p16001coll5/id/13199.

Elkington, J. (1998). Cannibals with forks. The triple bottom line of 21st century. Stony Creek: New Society Publishers.

Falk, B. (1997). Wood recycling: Opportunities for the woodwaste resource. Forest Products Journal, 47(6), 17.

Fletcher, K., Grose, L., \& Hawken, P. (2012). Fashion \& sustainability: Design for change. London: Laurence King.

Flint, I. (2001). Arcadian alchemy: Ecologically sustainable dyes for textiles from the eucalypt forest (Unpublished master's thesis). Adelaide: University of South Australia.

Global Safety Management. (2015). Safety data sheet: Aluminum potassium sulfate.

Haar, S., Schrader, E., \& Gatewood, B. M. (2013). Comparison of aluminum mordants on the colorfastness of natural dyes on cotton. Clothing and Textiles Research Journal, 31(2), 97-108.

Henry, B. (2012). Understanding the environmental impacts of wool: A review of life cycle assessment studies. Retrieved from Australian Wool Innovation and International Wool Textile Organization website. www.iwto.org/uploaded/publications/Understanding_Wool_LCA2_20120513.pdf.

Hon, D. N. S., \& Shiraishi, N. (2000). Wood and cellulosic chemistry, revised, and expanded. Boca Raton: CRC Press.

International Symposium and Exhibition of Natural Dyes. (2011). Conference proceedings, La Rochelle, France. http:// www.tcfdatu.org/files/Isend2011 Proceedings.pdf.

Işmal, Ö. E., Yıldırım, L., \& Özdoğan, E. (2014). Use of almond shell extracts plus biomordants as effective textile dye. Journal of Cleaner Production, 70, 61-67.

Kadolph, S. J., \& Casselman, K. D. (2004). In the bag: Contact natural dyes. Clothing and Textiles Research Journal, 22(1-2), $15-21$.

Kressman, F. W. (1916). Osage orange waste as a substitute for fustic dyewood. In J. A. Arnold (Ed.), Yearbook of the United States Department of Agriculture (pp. 201-204). Washington, DC: Washington Government Printing Office.

Littrell, M. A., \& Dickson, M. A. (1999). Social responsibility in the global market: Fair trade of cultural products. Thousand Oaks, CA: Sage Publications.

Lopes Ferreira, E. (2011). Natural dyes from cultivation or sustainable extraction from the local communities living in areas of Extractive Reserves in Brazil, South America. Paper presented at the meeting of International Symposium and Exhibition of Natural Dyes, La Rochelle, France. http://www.tcfdatu.org/files/lsend2011 Proceedings.pdf.

Marcus, R. T. (1998). The measurement of color. Color for science, art and technology, 1, 31-96.

Mirjalili, M., \& Karimi, L. (2013). Extraction and characterization of natural dye from green walnut shells and its use in dyeing polyamide: Focus on antibacterial properties. Journal of Chemistry. http://dx.doi.org/10.1155/2013/375352.

Moser, W. K., Hansen, M. H., Atchison, R. L., Brand, G. J., Butler, B. J., Crocker, S. J., \& Woodall, C. W. (2008). Kansas forests 2005. http://www.nrs.fs.fed.us/pubs/rb/rb_nrs26.pdf.

Peacock, J. C. (1901). Proceedings of the American Pharmaceutical Association at the Annual Meeting. Saint Louis.

Pizzi, A., Conradie, W. E., \& Jansen, A. (1986). Polyflavonoid tannins: A main cause of soft-rot failure in CCA-treated timber. Wood Science and Technology, 20(1), 71-81.

Prabhu, K. H., \& Bhute, A. S. (2012). Plant based natural dyes and mordants: A review. Journal of Natural Product and Plant Resources, 2(6), 649-664.

Puettmann, M. E., \& Wilson, J. B. (2007). Life-cycle analysis of wood products: cradle-to-gate LCl of residential wood building materials. Wood and Fiber Science, 37, 18-29.

Richards, L., \& Tyrl, R. J. (2005). Dyes from American native plants: A practical guide. Portland: Timberpress.

Rout, P. K., Naik, M. K., Naik, S. N., Goud, V. V., Das, L. M., \& Dalai, A. K. (2009). Supercritical $\mathrm{CO}_{2}$ fractionation of bio-oil produced from mixed biomass of wheat and wood sawdust. Energy and Fuels, 23(12), 6181-6188.

Russell, I. M. (2009). Sustainable wool production and processing. I. Oxford: Woodhead Publishing.

Rutter, L. (2013). Hedgerow heritage. Kansas Canopy: Newsletter of the Kansas Forest Service, 46, 4-9.

Saxena, S., \& Raja, A. S. M. (2014). Natural dyes: sources, chemistry, application and sustainability issues. In S. S. Muthu (Ed.), Roadmap to sustainable textiles and clothing (pp. 37-80). Singapore: Springer.

Seth, M. K. (2003). Trees and their economic importance. Botanical Review, 69(4), 321-376. 
Shahid, M., \& Mohammad, F. (2013). Recent advancements in natural dye applications: A review. Journal of Cleaner Production, 53, 310-331.

Sharma, A., \& Grover, E. (2011). Colour fastness of walnut dye on cotton. Indian Journal of Natural Products and Resources, 2(2), 164-169.

Sheep and Goats Death Loss. (2010). Washington, DC. http://www.usda.mannlib.cornell.edu/usda/current/sgdl/sgdl-0527-2010.pdf.

Sneddon, J., \& Rollin, B. (2010). Mulesing and animal ethics. Journal of Agricultural and Environmental Ethics, 23(4), 371-386.

Turgut, P., \& Algin, H. M. (2007). Limestone dust and wood sawdust as brick material. Building and Environment, 42(9), 3399-3403.

Vankar, P. S., Shanker, R., Mahanta, D., \& Tiwari, S. C. (2008). Ecofriendly sonicator dyeing of cotton with Rubia cordifolia Linn. using biomordant. Dyes and Pigments, 76, 207-212.

Windholz, M. (Ed.). (1983). The Merck Index: Encyclopedia of chemicals, drugs and biologicals (10th ed.). Rahway: Merck Co., Inc

\section{Submit your manuscript to a SpringerOpen ${ }^{\mathcal{O}}$} journal and benefit from:

- Convenient online submission

\section{- Rigorous peer review}

- Immediate publication on acceptance

- Open access: articles freely available online

- High visibility within the field

- Retaining the copyright to your article

Submit your next manuscript at $\boldsymbol{\nabla}$ springeropen.com 